\title{
シルバーハウジングにおける支援の仕組みと特性 THE ARRANGEMENT AND CHARACTERISTIC OF SUPPORT ON PUBLIC HOUSING FOR THE ELDERLY
}

\author{
縓平*, 横山俊 祐** \\ Pei GEN and Shunsuke YOKOYAMA
}

\begin{abstract}
How to promote the aged to be independent daily life is a big subject now. This paper analyze the support arrangement and characteristic on the Public Housing for the Elderly. It also shows the replenishment of the residents and welfare to support the health and life of the aged in realizing the high quality of the independent life. It's desirable that the notice should not be paid only to the public welfare, but also to the Co-support by the residents. Further, it states the demand of the housing plan for the aged to improve the interaction and living enviroments for guiding the support from the residents.
\end{abstract}

Keywords Public Housing for the Elderly, independent life, a assistance from resident, a assistance from welfare, support of health, support of life

高齢者住宅、自立生活、住み手援助、福祉援助、健康支援、生活支援

\section{1. 研究の背景と目的}

高齢者福祉は、新コールルドプランや介護保険制度の導入に代表さ れるように従来の施設型から在宅型へと展開し、在宅ケアサービス が重視されるようになうてきている。公営住宅事業においても、こ れまでの住宅困窎者への住宅供給に加えて、高齢者に対する福祉住 宅の供給が中心的な課題になりつつある。そうした背景を踏まえて、 1980 年代に初めて登場してきたシルバーハウジング（以下、S S H) は、高秢者の在宅を促進しつつ、安心して自立した生活を送ること を目的にした高跉者専用の公営住宅である。生活力が低下している 高齢者に対し生活援助員（以下、LS A）による支援体制を基本に しながら、バリアフリーや緊急通報装置を備えることで身体機能の 低下や緊急時への対応を図るといったハード・ソフト両面にわたる 制度に裹付けられた支援システムが採られている点に特徴がある。

S H の支援の仕組みに関する既往研究は、そうした特性に由来し て、L S Aなどの公的支援体制と高踰者の生活特性に焦点を当てた

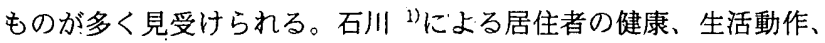
在宅福祉サ一ビスの利用状況等を把握することから、高龄者向け都 営住宅の展開方向を明らかにする研究や、菊澤 ${ }^{2)}$ 、園田 ${ }^{3)}$ 、杉野 ${ }^{4)}$ によるL S A の位置づけ・業務・生活援助サービスのあり方につい ての研究がある。また、宮本 ${ }^{5)}$ は高齢者の生活特性から S H 供給に
関わる生活支援のあり方について論述している。これらの研究は、 いずれも公的な扶助（公助）に重点を置いた研究と捉えられる。

しかしながら、「地域福祉は、公助・共助・自助の組み合わせで

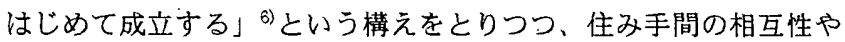
共同性などを集合住宅の本質的な優位性と捉えるならば、公助のあ り方の検討に加えて、寧ろ共に住み合うことを通して生み出される 住み手同士の自発的な相互扶助や支援（共助）を積極的に評価する 視点が求められる。

加えて、これまでの福祉政策では、高齢者を生活面・身体面にお ける弱者として捉え、一方的に保護すべき対象とする位置づけが一 般的であった。受動的な立場におかれることは、高龄者の有する生 活力、或いは社会参加の意欲を低下させ、ひいては生き生きとした 暮らしをも阻害することにつながりかねない。これに対して、高秢 者の生活の自立や地域で暮らすことの意味を考えるならば、高齢者 をあくまでも生活の主体者として位置づけ、自律的な生活力や自 助・共助を発揮する機会を如何に創出するかが問われる。

そこで本研究では、SHを対象に、これまでLSAや機械設備に よる福祉サービスが主眼となり殆どその実態や意義が明らかにされ なかった、住み手同士の自発的な相互扶助に焦点を当て、公助と相 対化しつつ、それらが健康面や生活面における住み手の安心感の獲
* 熊本大学大学院自然科学研究科 博士後期課程 - 修士 (文学)

** 熊本大学工学部環境システム工学科 助手·工修
Doctor Course, Graduate School of Science and Technology, Kumamoto University, M. Lit.

Research Assoc., Dept. of Architecture \& Civil Engineering, Faculty of Engineering, Kumamoto University, M. Eng. 
得や自立した生活の促進に向けてどのように寄与しているかを明ら かにすることを目的とする。特に、公助・共助を相対的に比較する ことで、各々の特性・意味を明らかにするとともに、両者の相互関 係を相乗性や補完性といった面から把握することを通して、支援に 関する全体的な仕組みの実態を明らかにする。

本研究がダイレクトに高齢者のための集住空間計画のあり方の提 案につながる訳ではない。㒵ろ、公助偏重のS Hに対して、共助の 有効性と必要性を明らかにすることで、今後の集住空間計画に住み 手間の相互性や共同性を促す視点が不可欠であることを提起するも のである。なお、具体的な集住空間の計画方法に関しては、別報で 詳細に論述する。

\section{2. 調査概要}

\section{1 調查対象団地の概要}

団地規模、住戸住棟配置におけるS Hの位置、一般住戸との混住 形態等が異なる九州圈内の 5 団地（IR ・ IZ ・ MO ・ SG・TS） を調査対象に選定した。各団地の計画概要と調查概要を表一 1 に、

\section{表-1 団地と調査概要}

\begin{tabular}{|c|c|c|c|c|c|}
\hline 団地名 & I R団地 & I Z団地 & MO団地 & SG团地 & T S団地 \\
\hline 事菜主体 & 入来町 & 熊本市 & 中間市 & 熊本県 & 北九州市 \\
\hline 竣工年 & $\mathrm{H} 6$ & $\mathrm{H} 6$ & $\mathrm{H} 8$ & $\mathrm{H} 4$ & H5 \\
\hline 模 & $1 \cdot 2$ 階建 & 7陸建 & 6.7階建 & 3階建 & $2 \cdot 3$ 陵建 \\
\hline 住㮴形式 & 2 户1住户 & 2 棟連結 & 2 棟連秥 & 2棟連結 & 4棟連結 \\
\hline 仕块版工 & 接地型 & 片廊下式 & 片廊下式 & 片廊下式 & 片廊下式 \\
\hline 全住戸数 & 50戸 & 129戸 & 52戸 & 30戸 & 31戸 \\
\hline S H戸数 & 10戸 & 70戸 & $28 \bar{F}$ & $25 \bar{F}$ & 30戸 \\
\hline 付属施設 & 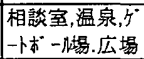 & $\begin{array}{l}\text { 相談室, 菜園 } \\
\text { 広埸 }\end{array}$ & 相談室,公園 & $\begin{array}{l}\text { 相談室,菜園 } \\
\text { 中庭.渡り廊下 }\end{array}$ & $\begin{array}{l}\text { 相靱室 } \\
\text { 花墙菜園 }\end{array}$ \\
\hline LSA数 & 1 名 & 名 & 名 & 1 名 & 1 名 \\
\hline 熟弱体制 & 宜間通殶 & 常住(疍2夜 1) & 通勤(荩1交替) & 常住 & 常 集 \\
\hline 翼 & 無 & 無 & 無 & 無 & $M A-$ \\
\hline 身 & 福祉課聏貝 & 委託派要 & 派遺 $n-k$ & 委託派遭 & 派遗 \\
\hline 所 & 役所 & 民間福祉施設 & 市宁他洺一 & 民間福祉施設 & 西部福祉会館 \\
\hline 勤務場所 & 福祉協䛨会 & 相談室 & 相談室 & 相談室 & 相談室 \\
\hline $\begin{array}{l}\text { 黑急通瓡 } \\
\text { 装 置 }\end{array}$ & 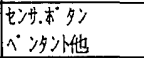 & 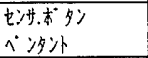 & 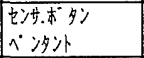 & \begin{tabular}{|l} 
七ンザ本多ン \\
ベンタ⿺
\end{tabular} & 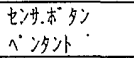 \\
\hline 7牲一恛収军 & $60.0 \%$ & $71.4 \%$ & $85.7 \%$ & $84.0 \%$ & $26.7 \%$ \\
\hline 七アリウグ数 & $6 \quad$ F & $30 \bar{F}$ & 11 戸 & $9 \bar{F}$ & $8 \bar{F}$ \\
\hline 調查時間 & 1997年9.10月 & $\begin{array}{l}1997 \text { 年9、10 } \\
\text { 月、1998年5.月 }\end{array}$ & 1998年7、8月 & $\begin{array}{l}\text { 1995年10月 } \\
\text { 1997年10月 }\end{array}$ & $\begin{array}{l}\text { 1995年10月 } \\
\text { 1997年7月 }\end{array}$ \\
\hline
\end{tabular}

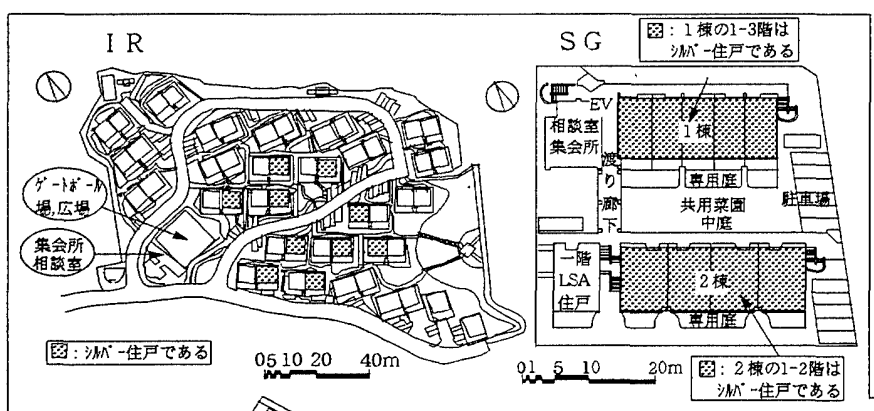

配置計画を図一 1 に示す。

S Hは、IR は一般世帯と二戸一形式で組み合わされた木造平屋、 IZ は二つの住棟の 3 階までの全てと 4 階の約半数といつた低中層 部分に、MO は二棟の内の 7 階建の一棟全て、SG は 3 階建て二棟 の内一棟の 3 階部分を除く全て、TS では L S A住戸一戸を除く全 てに配置されている。IRの他はSHの集約的配置がされている。

各団地における L S A の配属と勤務状況は、IR は非常駐の男性 1 名が昼間に巡回、MO も住み込みではない女性 2 名による交替制、 IZ は女性 3 名、SG·TS は女性 1 名による常住体制となっている。IR を除く業務拠点は相談室である。緊急時への対応、安否確認、困る ときの一時的援助、相談、情報提供など、L S A の業務は概好各団 地に共通である。また、各団地共通にボタンやペンダントの緊急通 報装置とリズムオンセンサ一等の通報設備が設置されている。

居住者の属性に関して（図-2）、年齢構成は MO·TS で 80 代 が 4 割前後を占め高跉化が進んでいるのに対して、IR では全て 80 才末满である。家族型は、IR で夫婦世帯が 4 割強と多いが、他は 各団地ともに、単身世帯、女性居住者が 7〜8割を占める。

\section{2 調查方法}

各団地のS H 居住の高龄者世帯を対象に、近所付き合いの相手と 内容、緊急時の対処法、L S A との交流実態、相談室の利用頻度な どに関するアンケート調查を予備的に実施し、高齢世帯の全体的な 概要や傾向を把握した。調查は、調查員が各戸を直接訪問し口頭に よる設問の説明と回答の聞き取り・記入を行う方法を採った。

更に、年齢、従前・新規居住に偏りがないようにし、各団地 S H 居住者の 3 5 割程度を対象に、身体状況、日常生活、相互扶助と 相手、通報設備の評価、L S A からの支援や評価等についての詳細 な実態や意識を把握する聞き取り調査を行った。なお、本研究では、
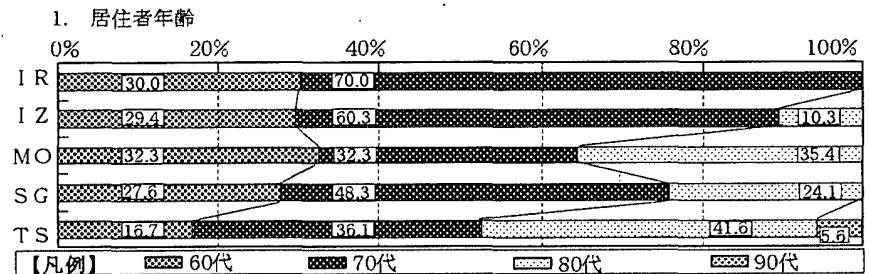

2. 家楼粠成 3. 珄別構成

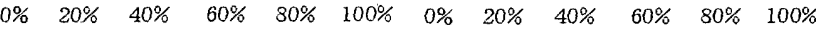

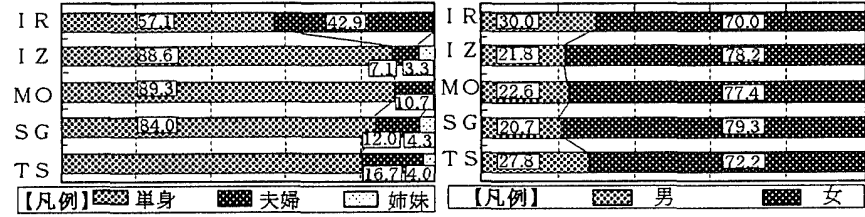

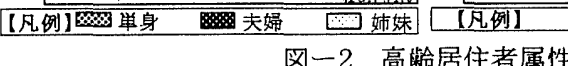

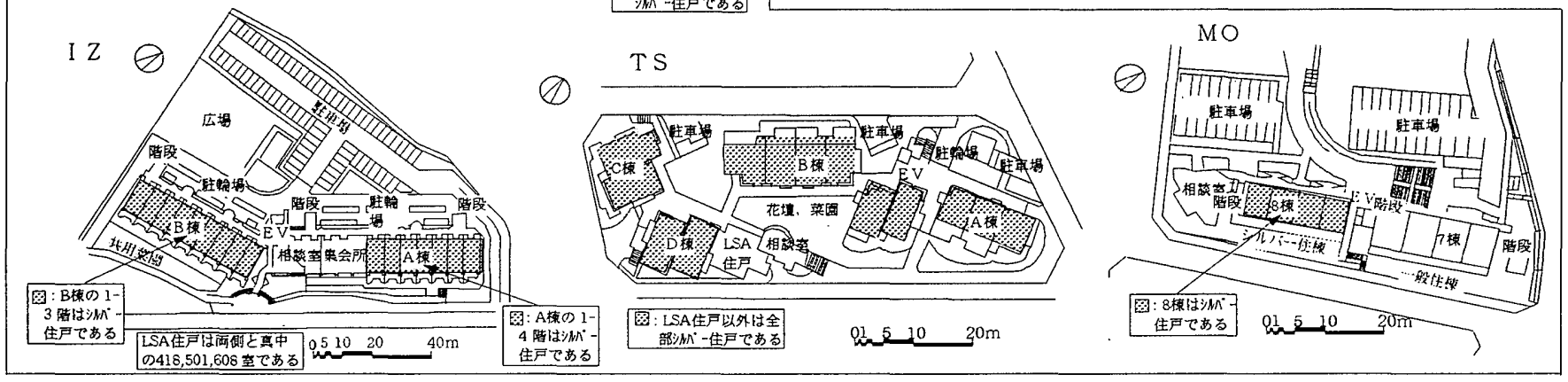

図-1 5 団地配置図 
高齢者に対する支援を体系的かつ具体的に明らかにするために、聞 き取り調査で得られたデータの分析に主眼をおいている。

\section{3. 健康支援}

\section{1 支援の主体と内容}

高齢者の健康面に対する支援を、緊急時の対応・日常の安否確認・ 健康相談の 3 つの側面に分け、それぞれの支援主体（表一-2）や支 援内容、評価（表一 $3 \cdot 4$ : 以下の文中〈番号〉・橎号は、表一 3 . 4 の意見番号に対応）について明らかにする。尚、ここでは支援の タイプを・L S A や緊急通報装置などに支援を依存する「制度型」・ 団地内住民や近くの身内などに依存する「住み手型」・制度と住み 手の両方に依存する「併用型」に分類して分析を進める（図一 3 ）。

\section{(1) 緊急時の対応}

各団地共に、リズムオンセンサー・緊急通報ボタンやペンダント などの機械設備が設置され、緊急事態が発生した際に、それを使っ てLSAや老人保健施設などに通報する仕組みが整えられている。 「制度型」が全体で $48 \%$ と最も多く、次いで「併用型」が $28 \%$ を

表一2 健康支援内容と主体
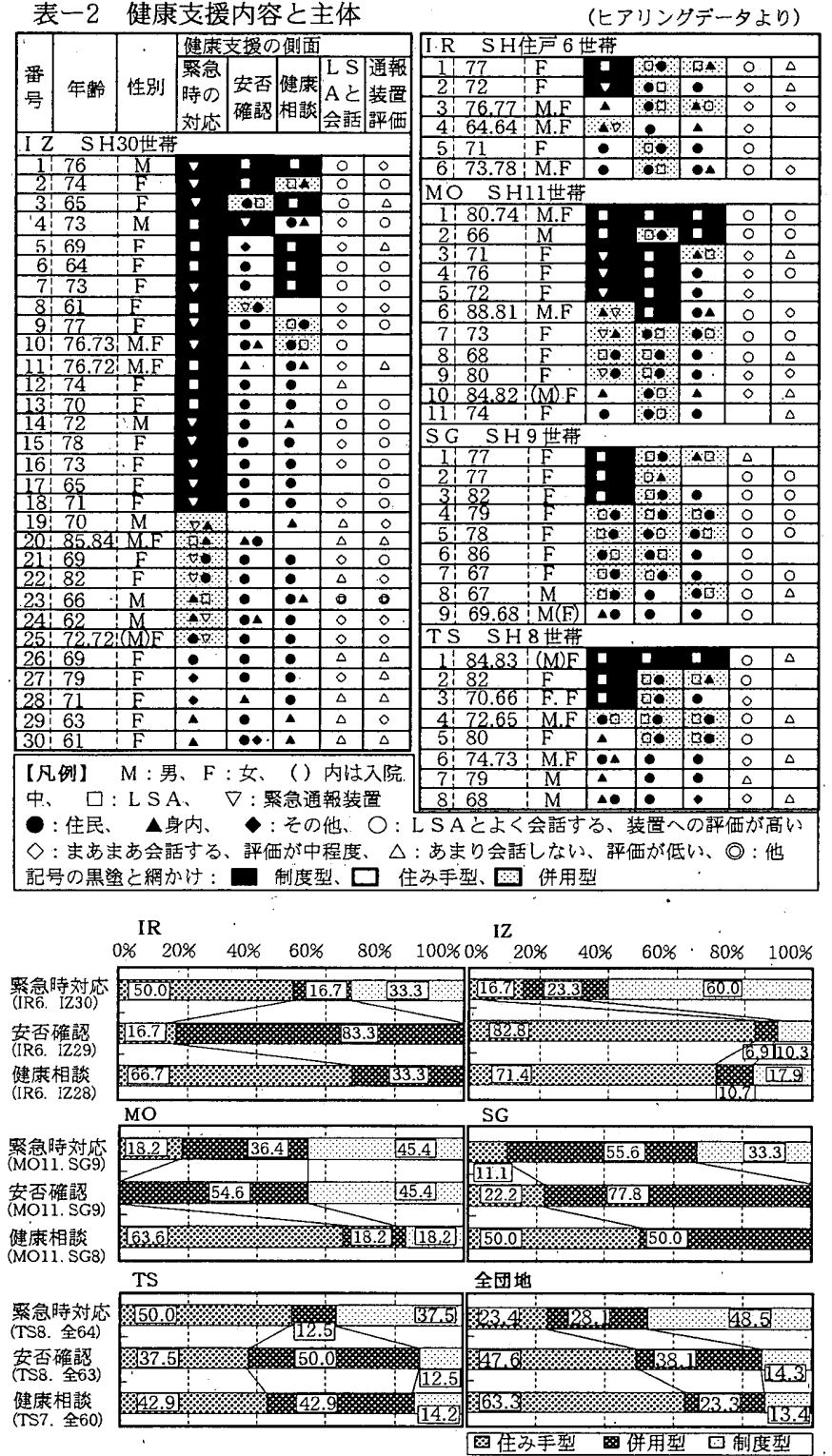

図一-3 健康支援に関する支援夕イプの状涗
占め、L S A や緊急通報装置に依存する傾向が強い。団地別に見る と、IZ、MO では「制度型」重視の傾向が窥えるが、SG では「併 用型」が $56 \%$ を占め、TS・IR では「住み手型」が $50 \%$ 占める。

L S A の勤務状況や考え方と制度依存の関係を見ると、IZ は夜 間専従のL S Aがいること（表-1）、MO ではL S Aが常住でない ものの：消防署への通報システムが完備していること〈(3)〉、SG では緊急時の対処に関するLS A の積極性〈(4)〉が制度依存を高め ていると考えられる。一方、IR ではL S Aが常住しないこと〈1 $\rangle$

が、制度依存を相対的に低いものにしている。

「制度型」では、婜急通報装置を「いざというときに安心」〈3〉 のように潜在的な不安に対応しうる保険として捉え、「ボタン」一 つでいつでも直ぐに連絡がつく」といった利便性や迅速性、確実性 が評価されている〈1〉。体力が低下し無理の利かない高齢者同士 では緊急時の支援には限度があり、住み手に依存するよりも制度が

表一 -3 健康支援に関する典型意見

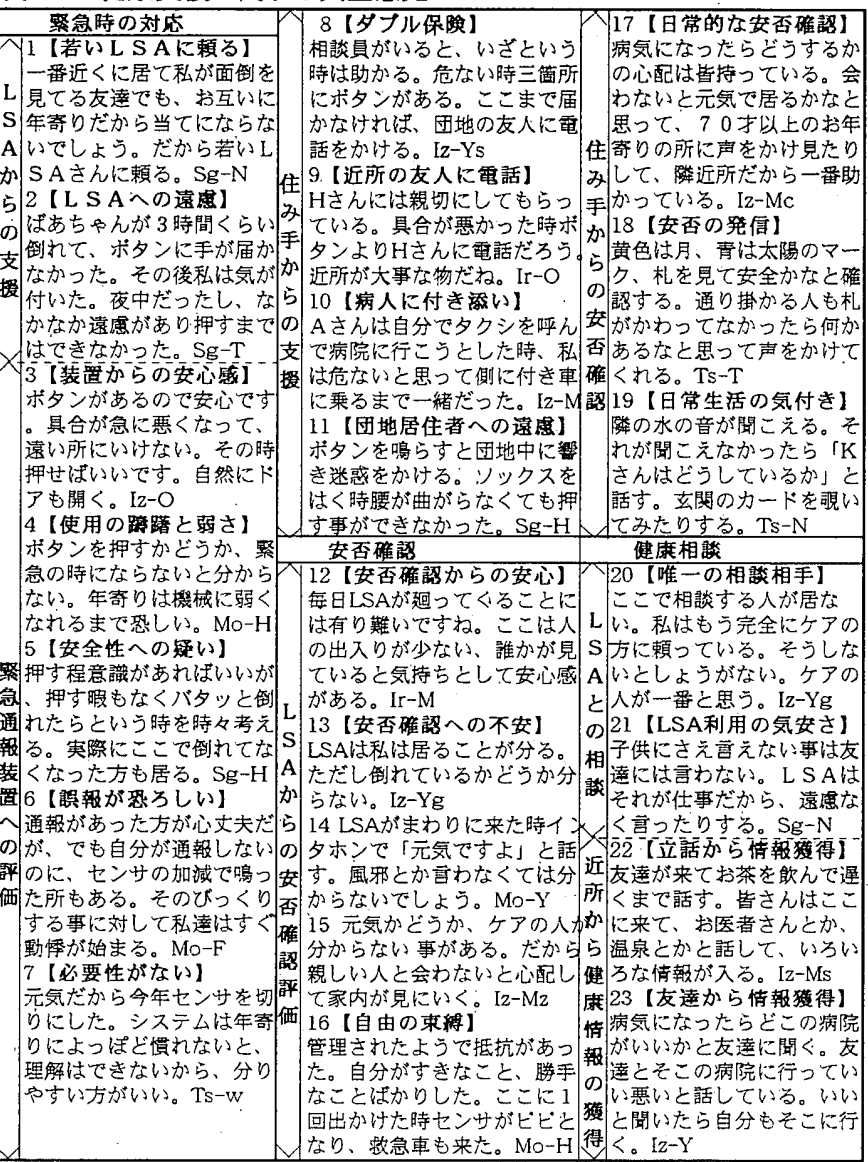

表 -4 健康支嗳に関するL S Aの典型意見

\begin{tabular}{|c|c|c|}
\hline 婜急対态 & 安否碓詔 & 健康相談 \\
\hline DここはLSAが仁 & (6) 1 日 2 回団地をまわる。家 & (11) 家の剠閵時に話をするだ \\
\hline & の紡問は & けて、、相談室に来る事がない \\
\hline 昵者の安心 & 回と個人 & のて、相談が多くない。IR \\
\hline SAの仕 & (7)1軒ずつ声をかけることは & (12) 相談場所は居住者の部屋 \\
\hline けることは一番 & 殆とししていない。最初した時 & が多い。 \\
\hline 何かある時、青ボタンを & らるさいと思われ、高䊀者は & 相談室に来た \\
\hline 押すとLSAや消防署に㸷が & 整骼を望んでいない。IZ & 凶みを話してく \\
\hline は安心てきると思 & (8) 朝 9 時と午後 3 時から 1 & れる。皆の状浣を把䖲するの \\
\hline 0 & 軒ずつインタホンを押して声 & だと思う。MO \\
\hline & をかけて整認する。MO & 前向きに考え \\
\hline 自分で買った血圧計て & (9) 朝6時15分にカーテンと起 & ることを助け、健康、悩み等 \\
\hline 急の時仕測ってやる。SG & きているかをチェックする & プライバシーの事の相談より \\
\hline 高粭者はち & 1日4回巡回する。SG & も䦎き役の感じが強い。SG \\
\hline とでボタンを押す人がいな & (11) 9時と18時に全住戸の札を & (15) 看護免許も何も持ってい \\
\hline W。 & 見てまわる。札をかけていな & ないのて、いろんな相談があ \\
\hline & & \\
\hline
\end{tabular}


優先されている。一方、「住夕手型」では、緊急通報装置への不信 感 $\langle 5\rangle$ 、低い操作能力 $\langle 4.7\rangle$ や誤作動〈6 、 L S A や団地全体に 迷惑を掛けること対する遠虑〈2・11〉等、緊急事態でも気軽に通 報装置を使用出来ない高齢者の配虑意識や低い操作能力が窺われる。 また、L S A や施設職員よりも近所の親しい人を煩わせる方が気が 楽である〈9）といった対処してもらう相手に対する親密さや肌理 の細やかさの違い〈10〉が評価されている。「併用型」は、状沇に 応じて装置と住み手とを使い分ける意識が見られる〈8〉。

\section{（2）安否確認}

各団地とも安否確認は、L S A の業務の一つになっているが、実 際には、IZ では「住み手型」が 83\%、他の 4 団地では「併用型」 が 50\%(TS) 83\%(IR)を占めて最も多い。団地毎の差異には、L S Aによる確認方法が作用していると考えられる。IZ では特定の病 弱な高齢者への直接確認以外は、センサーによる遠隔確認がなされ $\langle$ 〈7)、TS ・ SG では、安全カードやカーテンの開閉状況のチェッ ク等の間接確認〈(9)(1D)（SG では一日 4 回)、IR・MO では 2 回 各住戸を巡り高旍者に声をかける值接確認〈6)(8) が行われている。 L S Aに依存する「制度型」「併用型」の割合は、17\% (IZ)・63\% (TS) $78 \%$ (SG) ・ 83\%（IR） 100\%（MO）となり、確認方法 が、接触や会話等直接的であるほど、また頻度が高いほど、L S A 依存の傾向が強いことを示している。

一方、住み手依存の「住み手型」「併用型」の割合は、55\%(MO)・ $88 \%(\mathrm{TS}) \cdot 100 \%(\mathrm{IR}, \mathrm{SG})$ である。特に、接地型で開放的な玄 関や縁側のある IR、住戸間に隔壁のない連続バルコニーや縁側を 有するTS、低い隔壁によりバルコニー越しに瀿の様子が分り、玄 関脇に小空を有する SG、IZ など、生活の気配が周辺に伝わり易い 開放的な住戸計画が住み手の安否確認を容易にしている。

LS A 依存と住み手依存の関係は、IZ では相補的、他の 4 団地 では相乗的な関係になり、結果的に「併用型」が多くなっている。

「併用型」の多さは、L S A や通報装置と住み手による安否確認 との質的差異に起因している。業務としてのＬＳAによる安否確認 は、全居住者を対象に満遍なく行われることで、住み手に基本的な 安心感を与えている〈12〉。通報装置による遠隔確認や玄関のイン ターホンを通して高跲者に声を掛けることが多いが、通報装置によ り高齢者の在宅や安否（生存）は確認できるが、健康かどうかの把 握は難しい〈13〉、インターホンでは、体の具合が少し悪くても「元 気」と答える〈14〉など、L S A 、高齢者の具体的な健康状況 を的確に把握することが困難である〈15〉との指摘がある。

一方、住み手同士の安否確認は、立ち話や訪問などの直接対話 $\langle 17\rangle$ 、安全カードの点検〈18 、生活音の漏れ聞こえ〈19〉 や力 一テンの開閉など生活の様子を垣間見る自然監視、サイン化、日常 生活の機微や多様な生活シーンを捉えて多面的に、随時且つさりげ なく、他者の身体状況の確認が行われている。特に、直接対話する ことや生活に異変が感じられた時の迅速な訪問などによって、具体 的な健康状態の把握と対処がなされている。住み手による安否確認 はL S Aに比べて、より具体的で肌理の細かい身体状況の把握と支 援が行われ、住み手にとっての安心感は高い。

\section{(3) 健康相談}

L S A の業務には、高齢者の健康相談に応じるサービスの提供が あり、相談室が設置されている。しかし、IR のL S A は福祉協議
会と兼務であり、IZ では相談室が過剩に開放的であるため、あま り活用されていない〈(11)(12)。SG・TS の相談室は活用されている ものの、L S A に健康に関する専門的な知識がなく、聞き役にまわ ったり〈(14)〉、対応に苦慮した状況〈(15)〉が窺われる。住み手もL S Aによる健康相談業務を認知しているものの、全体で「住み手型」 が 63\%と最も多い。SG・TS では「住み手型」と「併用型」が的 半数を占めるが、他の 3 団地では「住み手型」が 6 割強を占める。

他に相談相手がいないこと〈20〉や、L S Aの業務として割り 切ること〈21〉などから、L S A に相談する場合もあるが、健康 面というプライバシー性の高い相談を持ちかけるには、住み手がL SAに対して充分な親密感や信頼感を有していないこと、L S Aの 健康面の知識や経験不足と年齢羊によって気持ちが共有できないこ と、或いは、相談室の堅苦しさやフォーマリティに対する抵抗感な どが窥われ、「制度型」への依存が低くなっている。

「住み手型」は、近隣の親しい人との普段の何気ない会話や付き 合いの中で、気軽に相談を行って倩報交換し、健康維持に役立てて いる〈22〉。また、同じ高跉者故に、健康は共通の話題になりやす く、病気治療や健康維持の方策に関して実際の経験に裏付けられた 情報に対する信頼性も高い〈23〉。生活圈が狭く、多様な情報メデ イアを活用できない高齢者にとって、近隣交流は健康相談の大きな 手がかりと情報源になっている。

\section{2 支援タイプの特性と要因}

緊急時の対応・安否確認・健康相談といった $3 つ の$ 側面に対する 支援主体には、「制度型」「住み手型」「併用型」が見られる。住み 手が誰からの支援を期待するかについては、支援の緊急性やプライ バシーの問題が関係しており、概水緊急時の対応では制度に、安否 確認では併用、健康相談では住み手に依存する傾向が見られる。

加えて、住み手による支援主体の選択の仕方には、近隣関係の粗 密と相手住戸との位置関係、L S A との人間関係、機械装置に対す る評価が大きく影響している。

\section{（1）近交流の拡がりと支援タイプの関係}

緊急時の対応・安否確認・健康相談の各々の場面に関して、「住 み手型」「併用型」「制度型」の依存タイプ別に、親しく付き合って いる相手の住戸の位置関係の遠近を 4 段階（同棟同階・同棟別階・ 別棟同階・別棟別階と相手がいない) に分けて、近箨交流の抾がり 方を見る（図一 4)。近隣交流の活発さや相手住戸の近接・離遠と いった位置関係と依存タイプには密接な関係が䂓われる。

「住み手型」は、3つの場面に共通して同棟同階に親しい人が 9 割前後存在している。特に緊急時の対応や安否確認を住み手に依存 するには、親しい人が近接していることが不可欠となっている。ま た、健康相談では、近接は若干低下している。

「制度型」は、親しい人の数が少ないなど近瞵関係が希薄な上に、 同棟同階の付き合いの割合が $2 \sim 5$ 割程度と低い。特に安否確認の 場合にはその傾向が強い。L S A や機械設備等は、近隣からの支援 に依存せずとも住み手の安心感を増すことに有効に機能していると 言える。一方、緊急時の対応では、近接する場合も5割強を占め、 制度に依存する傾向がある。

「併用型」は、同棟別階に親しい人がいる割合が、7割前後と高 いのが特徵である。自住戸から若干離れた位置に親しい人がいるた めに、全面的に住み手に依存せずに併用する原因だと考えられる。 
また、親しい人の近接は、3つの場面ともに影響を与えるが、特 に安否確認に強く作用し、健康相談への作用は相対的に弱い。

\section{（2）L S Aとの交流と支援タイプの関係}

同様に、各場面・各支援タイプ毎に、LSAとの会話の程度を見 る(図-5)。「制度型」や「併用型」は、L S A と会話を「よくす る]・[まあまあ］をあわせて 9 割前後を占め、LSSAとの交流頻度 が高い場合に制度に依存している。一方、「住み手型」では6割程 度に留まり、L S A との付き合いが希薄な場合には、制度よりも住 み手に依存する傾向がみられる。

制度による支援は、全ての居住者に一律に提供されることを旨と するにも関わらず、実際には、住み手とL S A との付き合い方や親 密さなどの対人関係によって左右されることが窥われる。

\section{（3）緊急通報装置の評価と支援タイプの関係}

緊急時の対応・安否確認において、各支援タイプ別の緊急通報装 置に対する評価を図一6に示す。緊急時の対応では、装置に対する 評価の高さが支援タイプに強く影響している。「住み手型」では肯

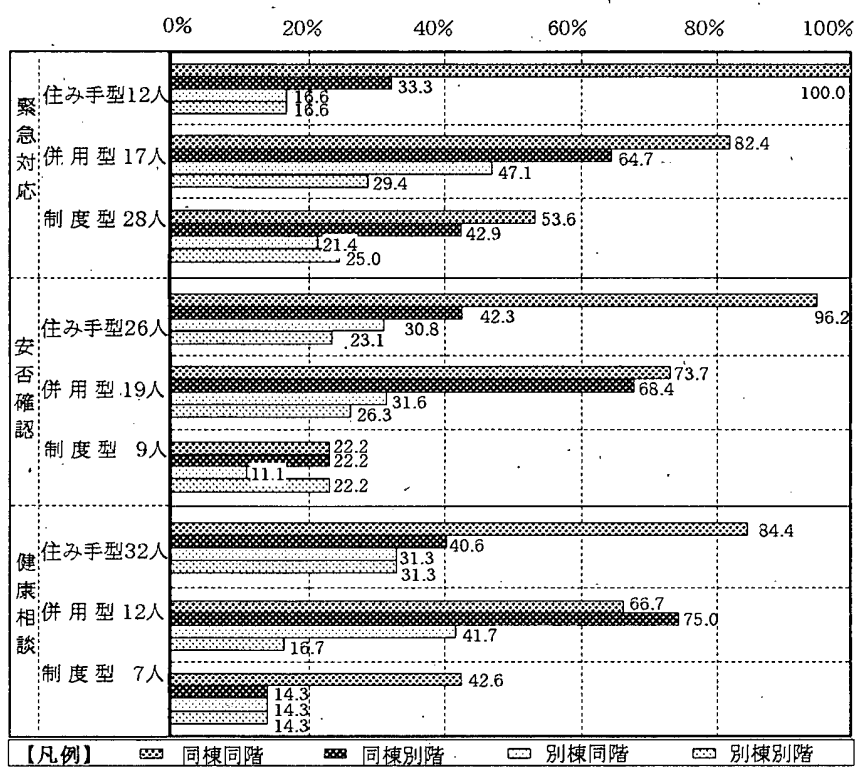

注 : 图-4は表-2とアンケートデータにより作られたもので,母数は表-2の回答人数に I R 団地高踰者を除いている

図一4＼cjkstart近隣関係と支援タイプとの相関関係

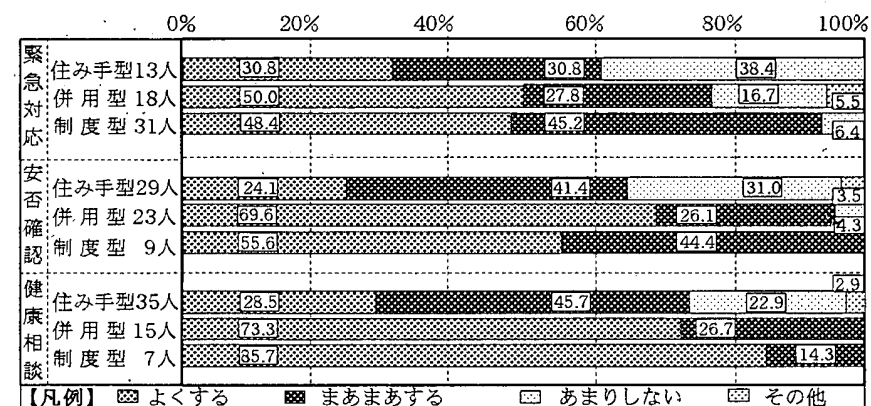

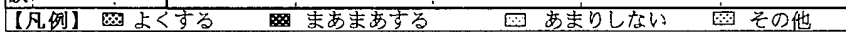

図ー5 L S Aとの会話程度と支援タイプとの相関関係

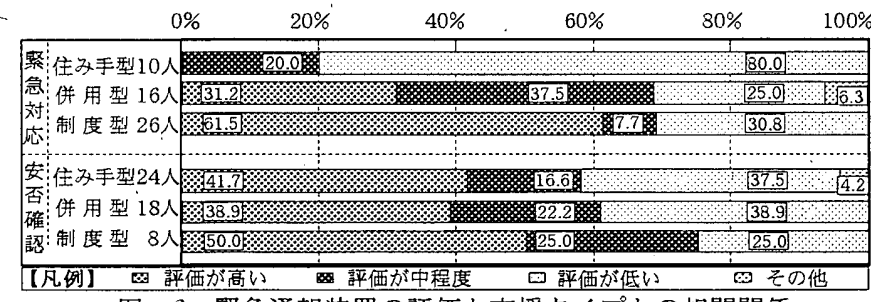

図一6＼cjkstart緊急通報装置の評価と支援タイプとの相関関係
定的な評価がまったく見られないのに対して、「制度型」では $61 \%$ と過半数を占めている。反面、「制度型」でも装置に対する評価が 低いものが 3 割程度見られ、装置に対する不信感を抱きながらもそ れに頼らざるを得ない住み手の存在は課題となろう。

安否確認では、支援タイプによる評価の違いは弱く、装置に対す る評価よりも近隣関係やL S A との人間関係が影響すると言える。

\section{4. 生活支援}

\section{1 支援タイプど内容の特性}

S Hは、基本的に自立した生活が可能なことが前提であるが、自 助力が低下している場合には、近隣やL S A 等から多様な支援を受 けることで生活を潤骬化することができる。ここでは、基本的生活 行為（家事・買い物）に関する定常的な支援、随時発生する支障に 対する一時的な支援、生活面で困ることの相談の 3 つの側面に着目 し、支援タイプと内容の特性を明らかにする（表一 $5 \cdot 6 \cdot 7$ (以 下《記号》は表 -5 中の世帯番号、〈数字〉数字は表 $-6 \cdot 7$ 中の 意見番号に対応)。健康支援の場合と同様に「制度型（LS A ルパー)小、住み手型」、「併用型」に支援タイプ（誰から支援され るか）を分類し、それぞれの支援方法に関する比較分析を進める。

（1）基本的な生活行為に対する定常的な支援

家事や買物などの基本的生活に対する定常的支援を 48\%(31/64) が受けている。支援タイプは、ヘルパーによる「制度型」が $6 \%(2 / 31)$ 、 「併用型」が 19\%(6/31)を占めるに過ぎず、L S Aからの支援は 「併用型」の 1 例のみである。「住み手型」が $74 \%(23 / 31)$ と、支 援の大半は住み手を中心に行われている。

定常的な支援に対し、L S A も業務外と割り切り、住み手の日常 生活に立ち入らないことや〈(1)(2)(4)(5)(7)〉、L S Aに対する住み手 の遠慮が原畐と考えられるものの〈25·28〉、生活能力の低下して いる高齢者に対して、制度に依存せずに住み仲間が自律的に支援す る仕組みは、生活の自立の促進に対する集住の意義と捉えられよう。 支援の内容は、調理の手伝いや料理のおすそ分け〈25.26〉、部屋 の掃除や片付けの手伝い〈27〉、買い物の代行や運搬等である。例 えば、慢性疾患の住み手《MO-9》に対して、近所が買い物をし、 病状に適した味付けの料理をおすそ分けするなど、住み手に不足し ている能力を補完するような家事労働を代行することで、生活の自 立を助けている〈24〉。住み手は相手の身体状況や生活スタイルな どを熟知しているが故に、肌理の細かい支援が行われている。と共 に、支援する側も家事行為のついでにといった余り負担のかからな い方法と意識を以て自分の能力に合わせた支援がなされている。

（2）支障に対する一時的な支援

病気や留守の時、或は力仕事が必要な時など随時生じる支障に対 する一時的な支援を受けるのは、63\%(40/64)を占める。その内 L SAによる「制度型」や「併用型」は各々 $10 \%(4 / 40)$ に過ぎず、「住 み手型」が $80 \%(32 / 40)$ と大半を占め、住み手への依存が強い。

各団地の L S A も，一時的支障に対しては、支援する意識を有して いる〈(1)(5)(6)〉。L S A による支援は、食事の提供、手紙・書類書 き、〈33〉、ごみ捨て〈34〉等、生活に媣く立ち入らない範囲で行わ れるのが特徽である。一方、住み手からは、病院への付き添い 《IZ-20》、病気の際の料理や部屋の片付け掃除等の家事手伝い 《IZ-3・22》、入浴の付き添い〈29〉等、突発的な支障の際にも基 
本的な生活が維持されるような支援や、留守時の盆栽や菜園の世話 の代行《汭-2・12》等、生活の多岐に渡る支援が特徵である。また 普段の生活の中でも電機製品の修理や日曜大工、重い物の移動など の力仕事〈30〉、或いは裁縫や料理の差し入れといった家事仕事 《TS-6》等、多様な扶助が行われて生活を潤滑化する。特に力仕 事は男性から女性へ、家事仕事は女性から男性へといった役割分担 がなされ、各自が有する能力や生活技術を発揮する状況が見られる。

\section{(3) 生活相談}

生活相談は、73\%(47/64)が行っている。その内 L S Aによる「制

表一 5 生活支援内容と主体、支援者と被支援者との関係

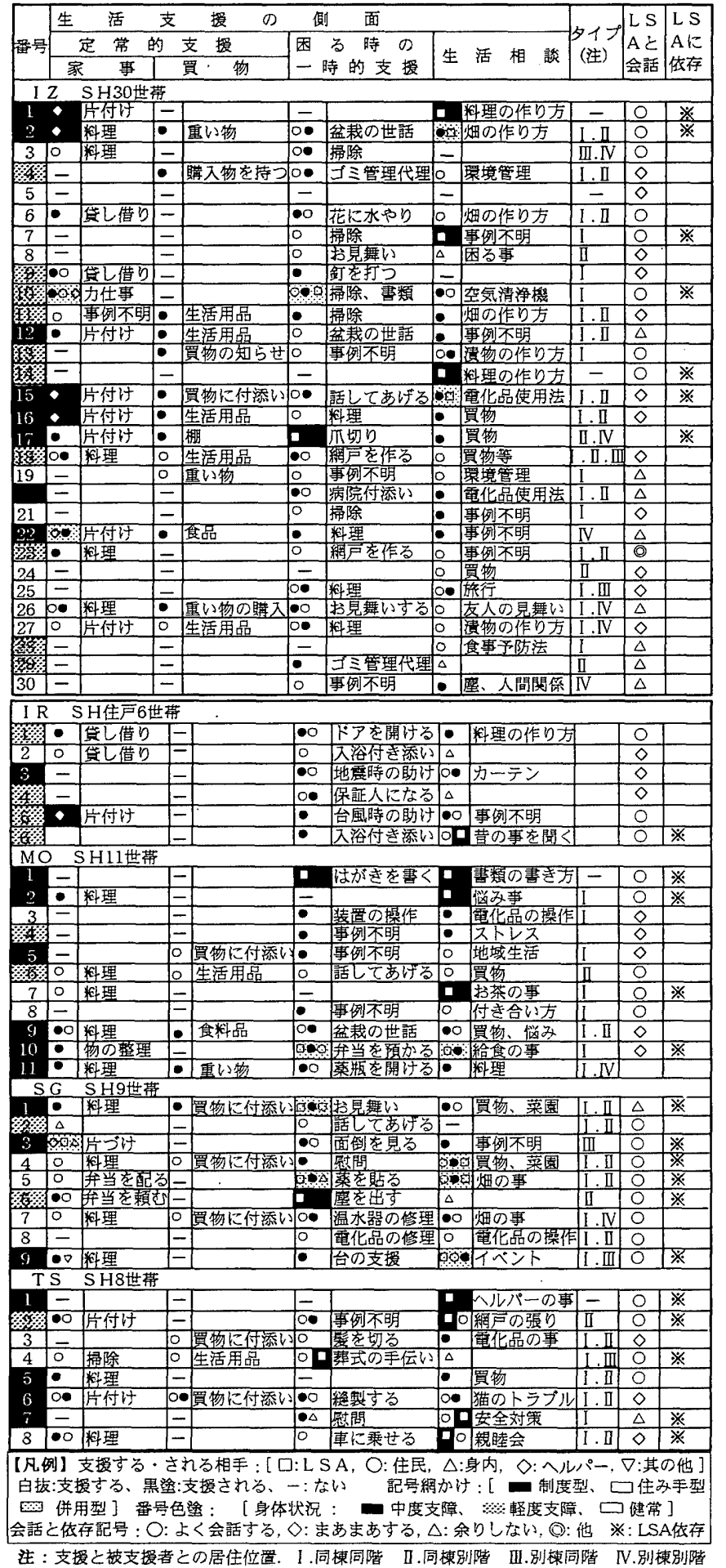

度型」が 23\%(11/47)、「併用型」が 13\%(6/47)で、他の支援場面 に比してL S A 依存の割合が相対的に高い。その理由は、生活相談 がL S A の業務であることを住み手が周知していること、および福 祉面や事務面に関するL S A の専門的な知識に期待して、様々な手 続きや悩みの相談が行われていることなどである〈37·38〉。

一方、「住み手型」は 64\%(30/47)を占め、ここでも支援の主体 は住み手が中心になっている。住み手への相談の内容は、悩み事、 身の上相談、仕事に関することなど深刻でプライバシーに関するこ とから、買い物、料理方法、電機製品の使用法など日常生活に密接 な関連のあること、菜園の作り方やイベントなどの趣味や娛楽に関 することまで、多岐に渡っている。

隣近所との日常的な付き合いの中で相互理解を深めることで、L SAよりも親密な関係の隣人の方が、より気楽に迅速に〈35〉、ま 表一6 生活支援に関する典型意見

\begin{tabular}{|c|c|}
\hline 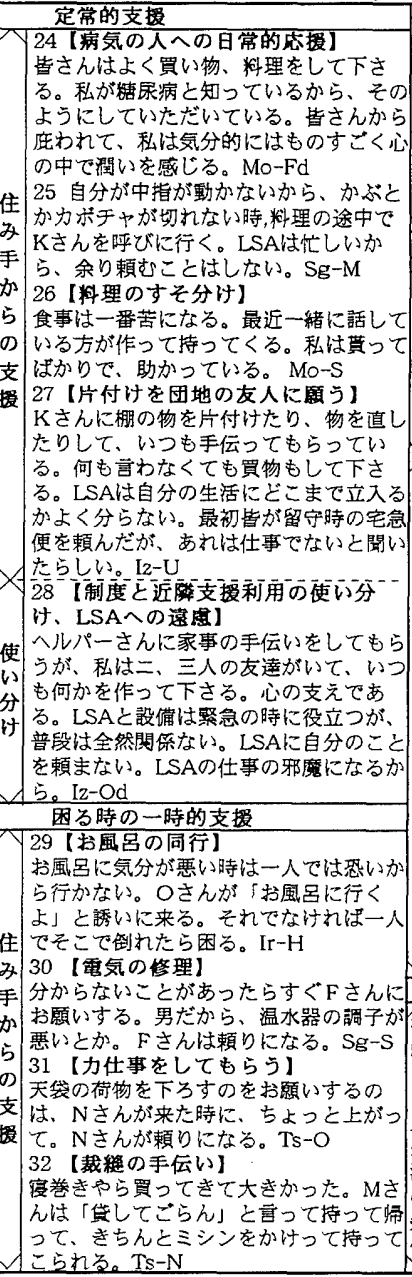 & 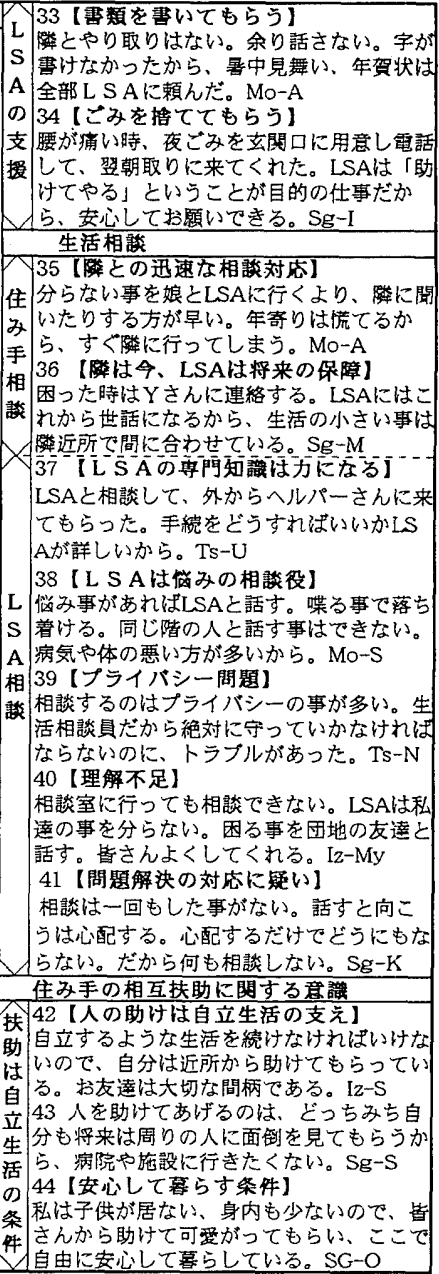 \\
\hline
\end{tabular}

\section{表一7 生活支援に関するL S A の典型意見}

家事等の支授

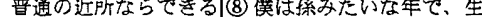

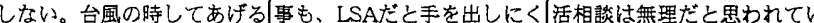
が、常駐しないのて、普通のい、一線を引いている。SG るだろう。IR

生活に開わらない。IR (6)退院した人への食事の気 (9)男珄洨料理の方法な (2)生活には深く入らない。手遣いや、家事授助をしたことどを聞きに来る。よく会う人 を出す事より見守る感じ。IZがある。これは私がするべきがものを閏きに来やすい。江 (3) 高龄者は昼間ディサービ ことだと思っている。TS 回蝶り過ざないように井戸 スセンターで昼食や入浴をし (7)買物に行ってほしい、電奵端会姜に参加する。なるだけ て過すようにしている。MOが切れたからとか、使えるも人が集まる中庭に出る。SG (4)どこまですればいいかの判のは使えという、甘光が全部(1LSAと住民の信頼関倸を持 断が鞋しい。徙の方がしてくこっちにくる。うまく行けばたいないとできない、親密に れる時は任せている。SG 感謝される。TS なり過ぎてもいけない。TS 
た小さなことでも親身に〈36〉相談できるなどの意識が窥われる。 加えて、近隣の方がより多様な知識や技術を有して的確な答えが得 られるという期待や人間関係などの団地生活を熟知しているという 安心感が評価されている。一方、L S Aに関しては、プライバシー 保持に関する信頼感の弱さ〈39〉 や住み手に対する理解不足〈40 や問題解決能力不足〈41〉を指摘する意見もあり、相談相手とし て十分な評価が得られていない。これに対してLS Aは、生活相談 を促進するために住み手との相互理解や信頼関係づくりに努めるこ とと、深入りしないことの均衡を図るような配慮が窥われる〈(11)(11)

\section{2 支援の主体・客体の特性}

生活面の支援は、LS Aに依存されにくい状況が明らかになった。 ここでは、生活の 3 側面（定常的支援・一時的支援・生活相談）に” おける支嗳の主体（する側になるか）・客体（される側になるか） の特性を身体状況や近隣関係、L S A との関係から明らかにし、各 支嗳の意味を考察する。

\section{（1）身体状況と支援の主体・客体の関係}

運動能力・疾患・視聴覚・生活能力を指標に、身体状況を健常・ 軽度支障・中度支障に分類し、それと生活支援の 3 つの倒面におけ る支援の客体・主体との関係を表一 8 に示す。基本的生活で定常的 支援を受ける割合は、各団地共通に身体状況によって異なる。中度 $72 \%$ 、軽度 $64 \%$ 、健常 16\%となり、身体的弱者が重点的に支援さ れている。中度では、住み手とヘルパーによる支援の併用が 2 割存 在し、ヘルパーの定期的で基本的な支援で不足する部分を住み手が きめ細かく補完している。支援の主体になる割合も健常は約半数を 占めるが、軽度・中度は各々 3 割前後亡少なく、客体と主体が比較 的分化し、健常が弱者を積極的に支援している状況が窺われる。

一時的支嗳の客体は中度・軽度ともに定常的支援之同様の傾向を 示す。反面、健常の約 $48 \%$ 支支援を受けること、中度・軽度の $52 \%$ 、 $57 \% か ゙$ 支援の主体となることが特徵である。身体状況と主体・客体 との関連は相対的に弱く、主体と客体が重複し、各住み手が支援す る、支援されるの両方の立場にあるケースも多く、身体的弱者であ っても住み手が各々の能力の範囲内で支嗳し合う状況を示している。 生活相談では、中度の $96 \%$ が客体（相談する）で、「制度型」、「併 用型」が各々 $28 \% 、 16 \%$ と高い割合を占めている。中度では福祉 の支援制度に関する相談も多く、前述のようにL S Aの尃門的な知 識への期待感を裏付ける結果となっている。

表一8 身体状況と支援の主体・客体の関係：（）は\%

\begin{tabular}{|c|c|c|c|c|c|c|}
\hline \multicolumn{7}{|c|}{ 常的支授 } \\
\hline & 支 & 授 & 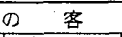 & 体 & 支 嗳 & I \\
\hline 体状涗 & 制度型 & 併用型 & 住み手型 & な & あ & な \\
\hline 中度 $[25]$ & $1(4.0)$ & $5(20.0)$ & $12(48.0)$ & $7(28.0)$ & $6(24.0)$ & $19(76.0)$ \\
\hline 埾度 [14] & $1(7.1)$ & $1(7.1)$ & $7(50.0)$ & $5(35.7)$ & $5(35.7)$ & $9(64.3)$ \\
\hline 健常 [25] & $0(0.0)$ & $0(0.0)$ & $4(16.0)$ & $21(84.0)$ & $12(48.0)$ & $13(52.0)$ \\
\hline 合計 [64] & $2(3.1)$ & $6(9.4)$ & $23(35.9)$ & $33(51.6)$ & $23(35.9)$ & \begin{tabular}{|ll}
41 & $(64.1)$ \\
\end{tabular} \\
\hline 困る時の一 & 的支授 & & & & & \\
\hline & 支 & 授 & 客 & 体 & 支 授 & 主 体 \\
\hline & 制度型 & 併用型 & 住多手型 & & あ & \\
\hline 中度 [25] & $2(8.0)$ & $2(8.0)$ & $15(60.0)$ & $6(24.0)$ & $13(52.0)$ & $12(48.0)$ \\
\hline 軽度 [14] & $1(7.0)$ & $1(7.1)$ & $7(50.0)$ & $5(35.7)$ & \begin{tabular}{|c|}
$8(57.1)$ \\
\end{tabular} & $6(42.9)$ \\
\hline 健常 [25] & $1(4.0)$ & $1(4.0)$ & $10(40.0)$ & $13(52.0)$ & $\begin{array}{|cc|}17 & (68.0) \\
\end{array}$ & $8(32.0$ \\
\hline 合計 [64] & $4(6.3)$ & $4(6.3)$ & $32(50.0)$ & $24(37.5)$ & $38 \quad(59.3)$ & $26 \quad 40$. \\
\hline 生活相談 & & & & & & \\
\hline & 支 & 嗳 & 客 & 体 & 支嗳 & D主 体 \\
\hline 身体状 & 制度型 & 併用型 & 住み手型 & & あ & な \\
\hline 中度 [25] & $7(28.0)$ & $4(16.0)$ & $13(52.0)$ & $1(.4 .0)$ & $9(36.0)$ & $16(64$ \\
\hline 軽度 [14] & $1(7.1)$ & $0(0.0)$ & $7(50.0)$ & $6(42.9)$ & $7(50.0)$ & $7(50.0$ \\
\hline 健常 [25] & $3(12.0)$ & 23 & $10(40.0)$ & $10(40.0)$ & $13(52.0)$ & $12(48.0$ \\
\hline 合計 [64] & $11(17.2)$ & $6(9.4)$ & $30 \quad(46.9$ & $17(26.6)$ & $29(45.3)$ & $35 \quad 54$. \\
\hline
\end{tabular}

\section{（2）近瞵関係と支援の主体・客体の関俰}

生活支援の 3 つの側面に関して、親しく付き合う近隣の居住位置 と支援の客体・主体との関係を表 -9 に示す（IR は全戸接地型の ため除外）。定常的な支援、一時的な支援とも、親しい人が同棟同 階に近接居住するほぞ、支援の主体・客体の割合が高くなり、客体 の場合に、「住み手型」が52\%を占める。親しい人との近接居住は、 住み手同士の相互扶助を生みだし易く、逆に相互の位置関係 が離遠や、親しい人がいない場合には、支援関係が生まれ難い。

一方、生活相談では、親しい人との位置関係の遠近は、主体（相 談を受ける）には影響するものの、客体（相談する）側への影響は 弱い。位置関係によらずに概水 7 割程度の住み手が相談をしている が、親しい人が、同棟同階や同棟別階にいる場合の相談相手は住み 手が中心になり、別棟や親しい人がいない場合は相対的に L S A 依 存の傾向が見られる。

生活支援の 3 つ側面において、近接からの支援に依存しないこ とと L S Aへの依存とは相互に密接な関係が窥われる。

\section{(3) L S A との関係}

生活の 3 側面で支援のいずれかをL S Aに依存している住み手と いずれも依存しない住み手に分けて、L S A との会話の頻度を見る (表 5 )。L S A 依存の場合には、L S A とよく会話する割合が 74\%(17/23)を占めるのに対して、依存しない場合には 27\%(11/41) に過ぎず、L S A との付き合い方と生活面での L S Aへの依存の仕 方は、相互に影響し合っている。また、団地別の L S A 依存の割合 は、SG・TS・MOでは、各々 67\%(6/9)・62.5\%(5/8)・40\%(4/10) と高く、IZ・IRでは、23\%(7/30)：17\%(1/6)と低い。

ここで、団地別にL S Aとのコミュニケーションや親しい関係づ くりの手がかりとなる相談室への来訪頻度を見ると、TS ・ MO で 週に 1.2 回以上が 4 割強を占めて最もよく来訪し、IR・IZ では、 来訪頻度が極めて低い（図-7)。即ち、相談室への来訪が多い団 地では、生活面でのL S Aへの依存が強い傾向が窺われる。

来訪頻度とLSAとの会話の内容との関係を見ると（図一-8）、 頻度が高いほど、健康や生活面の相談や世間話などプライバシーに 関係することや楽遊的な内容が多く、低ければ、挨拶や一般的な連 絡事項の伝達など最小限のコミュニケーションに留まっている。相 談室への頻繁な来訪が、L S Aへの親密感や信頼感を深めるなどの 人間関係を創り出し、結果的にL S A 依存につながると言えよう。

表一9 親しい人の居住位置と支援の主体・客体の関係：（）は\% 基本的生活への定常的支授

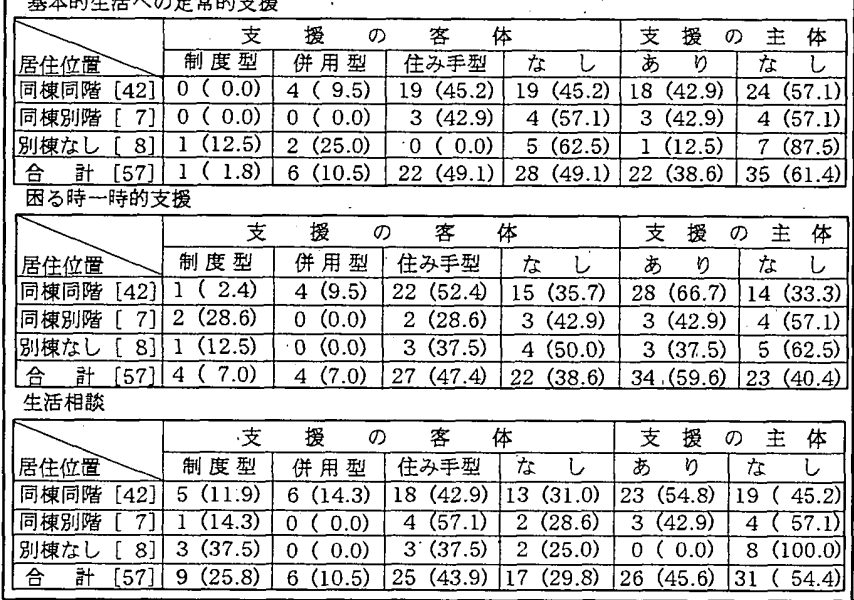


相談窒への来訪頻度の違いには、相談室の位置やしつらえといっ たハード面と運営方法とが影瑤している。SG・TS の相談室は住 み手の溜まり場である菜園（TS）や渡り廊下・中庭（SG）に面し、 溜まり場に奇るついでに気軽に立ち寄ることができること、MOは、 L S A により新聞や雑誌、TV が用意され、住み手の来訪時にはお 茶をだして、お喋りする等の娛楽室化していることにより、来館頻 度が高い。一方、IR では、L S A が役場の職員で他と兼務のため に、相裧室に不在のこと、IZ では通路に面して全面ガラス張りに 近く、視線が透過することにより、相談機能が十分に発揮されない。

L S Aとの対人関係には、団地コミュニティへのL S Aの関わり 方や相談室の活用状況に加え、SH の集合規模が作用していると考 えられる。70 戸規模の IZ は、L S Aとの会話を「よくする」のが 29\%（8／28）に留まる反面、「あまりしない」も同数存在してい る。一方、10 戸規模の IR は、L S A の勤務体制に起因してコミコ ニティへの関わり方や相談室の利用が低いものの、会話を「よくす る」と「まあまあ」が各々 $50 \%(3 / 6)$ を占め、交流頻度が高い。
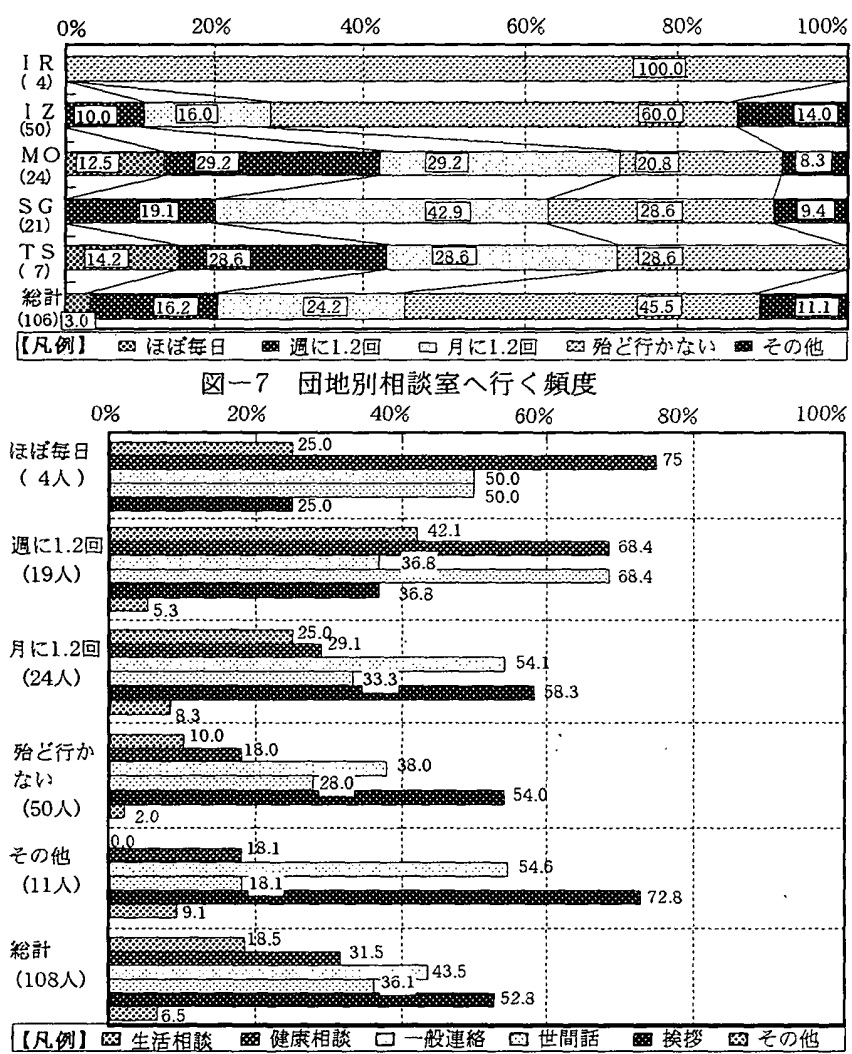

図一8 相談室へ行く頻度之相談内容

\section{5 .まとめ}

S H の高龄者は、健康面や生活面に対するL S A や機械設備によ る制度的な支援「公助」と、住み手同士の相互扶助による自律的な 支援「共助」によって、自立した生活が可能になっている。健康支 援の側面では制度型に依存する傾向があるのに対して、生活支援の 側面は概ね住み手型を中心に行われている。

「公助」と「共助」の支援の仕組みの特性は相補性や相乗性を有 する。高䀫者の強い不安の一つである緊急時の対応や安否確認に関 しては、通報装置やL S Aによる支援を基本としながらも、住み手 による支援が制度支援の制約を補ったり、重層的に作用することで、
安心感を高めている。また、健康相談や生活相談では、住み手は相 談の内容やL S A との人間関係、あるいは親しい住み手の有無や位 置関係などに応じて、公助と共助を活用している。両者が併存する ことで、支援の内容と方法が多様化し、個々の住み手の状況の違い にきめ細かく対応しうることにつながる。生活の自立に向けての定 常的・一時的支援では、職務規定上の制約によって、L S A が入院 やヘルパー派遣までのつなぎの支援に留まる状況に対して、住み手 による共助が積極的に行われ、生活面での自立が可能となっている。

公助と共助が相補的・相乗的に機能している背景には、両者の質 的な差暴といった特性が存在している。公助は、「いつでも誰にで も同じようにサービスを提供する」という一律性や安定性・確実性 などの優位性をもつ反面、業務内容の規定や機械設備からの制約に よって画一的な支援方法や個々の住み手の日常生活に深く介入しな いという限界がある。さらに、制度によって担保されている支援の 一律性も、実際には住み手による機械設備の評価やL S A との対人 関係に左右されて、偏りが見られる。またＬＳAが支援者で住み手 は被支援者であるという一方的な関係も存在している。

一方、共助は、住み手個々の多様な支援のニーズや状況の違いに 応じて弾力的に、きめ細やかに対応する柔軟性や個別性、また、日 常生活や健康の様々な場面に対応しうるといった支援の対象・内容 ・方法の広さと深さ、親密な関係に裏付けられた支援依頼の気軽さ や支援の主体にも客体にもなれるという相互性などの有効性がある。 また、生活の自立や安心感の高揚といった側面に加えて、相互支援 を通じて住み手自身の存在価値が確認され、生きがいにつながって いる。反面、共助は近隣関係に大きく影響され、漞しい付き合いが ない場合や、近接していない場合には、住み手同士の相互支援は難 しいといった問題も窥われる。

公助・共助各々の優位性や有効性が、互いのデメリットを解消す る方向に作用している点や、「併用型」にみられる、制度的支援を 基本とした上で、個別の状況に応じた多様で柔軟な共助が展開され ることで支援の質が高まる点に、両者の存在意義と必要性が認めら れる。高齢者への支援は、制度的に一方的に提供されるものだけに 傾斜することなく、住み手による自律的・主体的・相互的な支援を 触発誘導しつつ、両者が重層化するような計画が求められよう。

注

1) 石川弥栄子、八藤後猛、野村歡「シルバーピア居住者の年路別に見た 健康及び日常生活状況の考察」 日本建築学会計画系論文集、PP93-99、 1998.8

2）菊澤康子、青野香緎、中島論「LS A 位置付けと生活援助サービス」 都市住宅学 11 号、PP44-49、1995

3）園田真理子、古川容子「高路者住宅における管理、運営システムのあ り方に閶する研究」都市住宅学 11 号、PP56-61、1995

4）杉野美佐子、小河達之、菊澤康子、宮本美奈「シルバーハウジングに 関する研究ーL S Aの業務と課題」都市住宅学 19 号、PP103-113。 1997

5) 宮本美奈、菊澤康子、杉野美佐子「シルバーハウジングに関する研究 一入居者の日常生活実態と生活支援のあり方」都市住宅学 19 号、 PP103-113、1997

6) 上野干鶴子「介讙保隊の課題と市民参画」每日新聞朝刊、2000.1.14ロ

*本研究は 1996 年度日本建栄学会大会学術講演会にて発表した内容を加筆 修正したものである。 